\title{
Molecular Analysis of Hereditary Deficiency of the Third Component of Complement (C3) in Two Sisters
}

\author{
Wataru Matsuyama, Masanori Nakagawa, Hiroshi Takashima, Fuminaga Muranaga, Yuji Sano* \\ and Mitsuhiro OsAME
}

\begin{abstract}
We report two sisters with hereditary deficiency of the third complement component (C3) and a homozygous mutation at C3303G (Tyr1081Stop) of the gene. They developed systemic lupus erythematosus-like symptoms during adolescence. Their $\mathrm{C} 3$ were not detected in serum immunochemically. Their mother and a brother had half of the normal $\mathrm{C} 3$ levels and a heterozygous mutation in the same position. Western blot analysis of murine L-cells transfected with the mutant $\mathrm{C} 3$ cDNA showed no $\mathrm{C} 3$ protein, however mRNA was detectable using reverse-transcriptase polymerase chain reaction. To the best of our knowledge, this is the first report of $\mathrm{C} 3$ deficiency due to a stop codon in the gene.

(Internal Medicine 40: 1254-1258, 2001)
\end{abstract}

Key words: stop codon, systemic lupus erythematosus

\section{Introduction}

Inherited third component of complement (C3) deficiency is a rare disease, which is characterized by recurrent infections with pyogenic encapsulated bacteria and certain immune complex-related disorders including membranoproliferative glomerulonephritis, systemic lupus erythematosus (SLE), and vasculitis. Since 1972, over 20 inherited C3 deficiency cases have been described, however the responsible gene mutations, such as point mutation, gene deletions and splice site mutations in the $\mathrm{C} 3$ genome, have been reported in only a few of these families (1-3). We previously reported two sisters with hereditary C3 deficiency exhibiting SLE-like symptoms (4). To clarify the molecular mechanism in these sisters, we analyzed the sequence of the $\mathrm{C} 3$ gene and the expression of the gene in culture cells.
Patients' Report

The details of clinical and laboratory findings in this family have been reported previously (4). Briefly, patient 1 was a 36year-old woman born by normal delivery after an uneventful pregnancy. During her early childhood, she was in good health and showed no signs of proteinuria or hypertension. However, at 16 years of age, she developed SLE-like symptoms. The diagnosis of C3 deficiency was made at the age of 19, due to the absence of $\mathrm{C} 3$ as determined immunochemically (Table 1). However, a slight amount of $\mathrm{C} 3$ activity as well as total complement activity was present. She developed high fever, butterfly rash, Raynaud's phenomenon, intermittent arthralgia and photosensitivity. Patient 2 was a 34-year-old woman (the younger sister of patient 1) with an almost identical clinical course and symptomatology. She was diagnosed with C3 deficiency at 14 years of age. The patients were treated with corticosteroid hormone with relatively good control of symptoms. Both the mother and brother were in good health despite their C 3 concentrations being approximately half of normal serum C3 levels as determined immunochemically.

\section{Sequence Analysis of $C 3$ and Expression Study of C3 Protein}

\section{Methods \\ cDNA synthesis and sequence}

First strand cDNA was obtained by using $\mathrm{RNase}^{-}{ }^{-}$reverse transcriptase (Superscript ${ }^{\mathrm{TM}}$ preamplification system for first strand cDNA synthesis, Invitrogen, Groningen, The Netherlands) from Epstein-Barr virus transformed lymphoblasts. The cDNA of $C 3$ was amplified and its sequence determined by direct sequencing of both sense and antisense strands with $\mathrm{ABI}$ PRISM $^{\mathrm{TM}} 310$ Genetic Analyzer using the fluorescence-labeled primers.

Genomic DNA

Genomic DNA was isolated from whole blood obtained from

From the Third Department of Internal Medicine, Kagoshima University Faculty of Medicine, Kagoshima and *Tokushima Public Health Center, Tokushima Received for publication June 18, 2001; Accepted for publication September 3, 2001

Reprint requests should be addressed to Dr. Masanori Nakagawa, the Third Department of Internal Medicine, Kagoshima University Faculty of Medicine, 8-351 Sakuragaoka, Kagoshima 890-8520 
Hereditary C3 Deficiency in Sisters

Table 1. Complement Component Profiles in the Sisters with C3 Deficiency (4)

\begin{tabular}{|c|c|c|c|}
\hline & Patient 1 & Patient 2 & $\begin{array}{l}\text { Pooled normal } \\
\text { human serum }\end{array}$ \\
\hline \multicolumn{4}{|l|}{ Hemolytic activities } \\
\hline CH50 $(\mu / \mathrm{ml})$ & 6.3 & 5.8 & 40.0 \\
\hline $\mathrm{C} 1(\mathrm{SFU} / \mathrm{ml})$ & $90,400(87.9 \%)^{*}$ & $100,000(97.3 \%)^{*}$ & 102,800 \\
\hline $\mathrm{C} 4$ & $26,400 \quad(39.8 \%)$ & $26,400 \quad(39.8 \%)$ & 66,400 \\
\hline $\mathrm{C} 2$ & $430 \quad(43.9 \%)$ & $380 \quad(38.8 \%)$ & 980 \\
\hline $\mathrm{C} 3$ & $320 \quad(0.7 \%)$ & $270 \quad(0.6 \%)$ & 47,000 \\
\hline $\mathrm{C} 5$ & $229,000(110.1 \%)$ & $229,000(110.1 \%)$ & 208,000 \\
\hline C6 & $7,900(148.0 \%)$ & $7,200(134.8 \%)$ & 5,340 \\
\hline $\mathrm{C} 7$ & $22,000(183.3 \%)$ & $19,800(165.0 \%)$ & 12,000 \\
\hline $\mathrm{C} 8$ & $22,400 \quad(81.8 \%)$ & $21,800 \quad(79.6 \%)$ & 27,400 \\
\hline C9 & $29,600(197.3 \%)$ & $30,000(200.0 \%)$ & 15,000 \\
\hline \multicolumn{4}{|c|}{ Protein concentrations } \\
\hline $\mathrm{C} 1 \mathrm{q}^{* *}$ & 141 & 141 & \\
\hline $\mathrm{C} 4$ & 11.7 & 11.7 & \\
\hline $\mathrm{C} 3$ & ND & ND & \\
\hline C5 & 110 & 130 & \\
\hline Factor B & 24.9 & 25.9 & \\
\hline $\mathrm{C} 1$-inactivator & 115 & 119 & \\
\hline $\mathrm{C} 3 \mathrm{~b}$-inactivator & 100 & 110 & \\
\hline
\end{tabular}

*Numbers in parentheses are $\%$ of pooled normal human serum (NHS). **Normal ranges: $\mathrm{C} 1 \mathrm{q}=60-130 \% \mathrm{NHS} ; \mathrm{C} 4=20-50 \mathrm{mg} / \mathrm{dl} ; \mathrm{C} 3=60-110 \mathrm{mg} / \mathrm{dl} ; \mathrm{C} 5=85-125 \% \mathrm{NHS}$; factor $\mathrm{B}=13-$ $23 \mathrm{mg} / \mathrm{dl}$; C1-inactivator $=75-145 \% \mathrm{NHS}$; C3b-inactivator $=60-140 \% \mathrm{NHS}$. SFU: site forming units, ND: not detected.

the patients, the mother and the brother in order to compare and confirm the sequence of $C 3$. Also, genomic DNA isolated from 50 healthy volunteers served as controls after informed consent for participation in this study had been obtained.

\section{Construction of full-length normal and mutant C3 cDNA}

Human liver cDNA library (Takara Shuzo, Tokyo) was screened by colony hybridization and full-length $C 3 \mathrm{cDNA}$ was selected. The $C 3$ cDNA was subcloned into pAP3neo vector (Takara Shuzo, Tokyo) using NotI restriction site. We amplified the cDNA of the present cases including the proposed mutation site and ligated the amplified product into the fulllength C3 cDNA clone using SfiI and NarI restriction enzymes.

\section{Cell culture and transfection}

The subclone of murine L-cell used in this study expressed no endogenous $\mathrm{C} 3$ protein or mRNA (data not shown). Murine L-cells were cultured in $5 \% \mathrm{CO}_{2}$ incubator at $37^{\circ} \mathrm{C}$ in Dulbecco's modified Eagle's medium (Nissui, Tokyo) supplemented with $10 \%$ fetal calf serum, $2 \mathrm{mM}$ glutamine, 100 units $/ \mathrm{ml}$ penicillin, and $100 \mu \mathrm{g} / \mathrm{ml}$ streptomycin. Murine L-cells were stabilized and transfected with 5-35 $\mu \mathrm{g}$ of C3 plasmid DNA together with $C 3$ mutant and Lipofectin reagent (Invitrogen, Groningen, The Netherlands) according to the manufacturer's protocol. Three days after transfection, selection was started with neomycin $(500 \mu \mathrm{g} / \mathrm{ml}$, Life Technologies) and indepen- dent clones were randomly chosen after 3 weeks of selection.

\section{Expression of $C 3$ protein and $m R N A$}

Murine L-cells, transfected with normal and mutant $C 3$ cDNA, were harvested and the expression of $\mathrm{C} 3$ proteins was examined by Western blot method using a monoclonal antibody for the $\beta$-chain of $\mathrm{C} 3$ (Progen, Heidelberg). Expression of normal $C 3$ and mutant $C 3$ mRNA were investigated by the reverse-transcriptase polymerase chain reaction (RT-PCR) method using the primers $5^{\prime}$-ATGGGACCCACCTCAGGTC$3^{\prime}$ and $5^{\prime}$-CACCTTCTCCACCACTTGGG-3' according to the standard protocol.

\section{Results}

By sequencing the cDNA obtained from the Epstein-Barr virus transformed lymphoblasts, we found a homozygous point mutation (exon 26, C 3303 G, Try 1081 Stop) in the C3 gene of the two sisters and a heterozygous mutation in their mother and brother. This mutation, which generated a new recognition site for a restriction enzyme $B \ln I$, was confirmed by sequencing genomic DNA isolated from whole blood using primers, 5'-CTGCAGGGTACACCCAGCAG-3' and 5'-TTCTTGGTGTATCACGGGCG-3', corresponding to exon 25 and exon 26 , respectively. Using the primers described above, the PCR products of the patients, mother, brother and normal controls were 
A

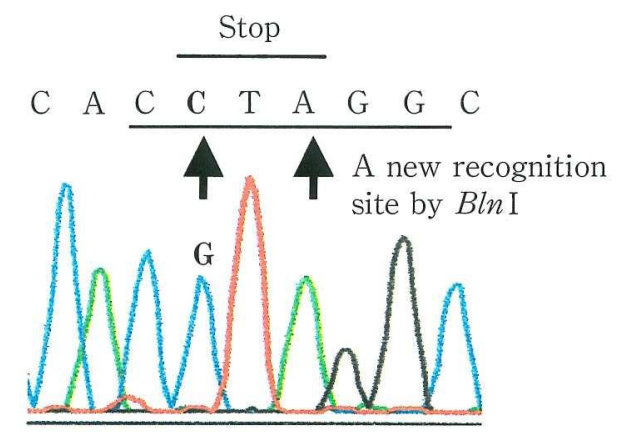

$\mathrm{B}$

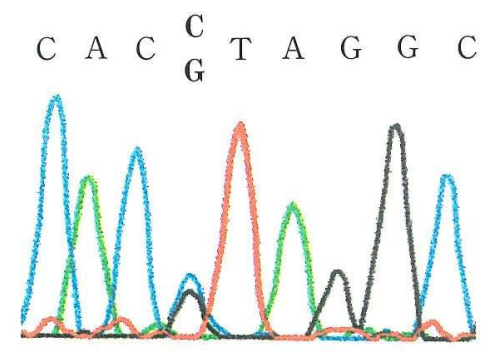

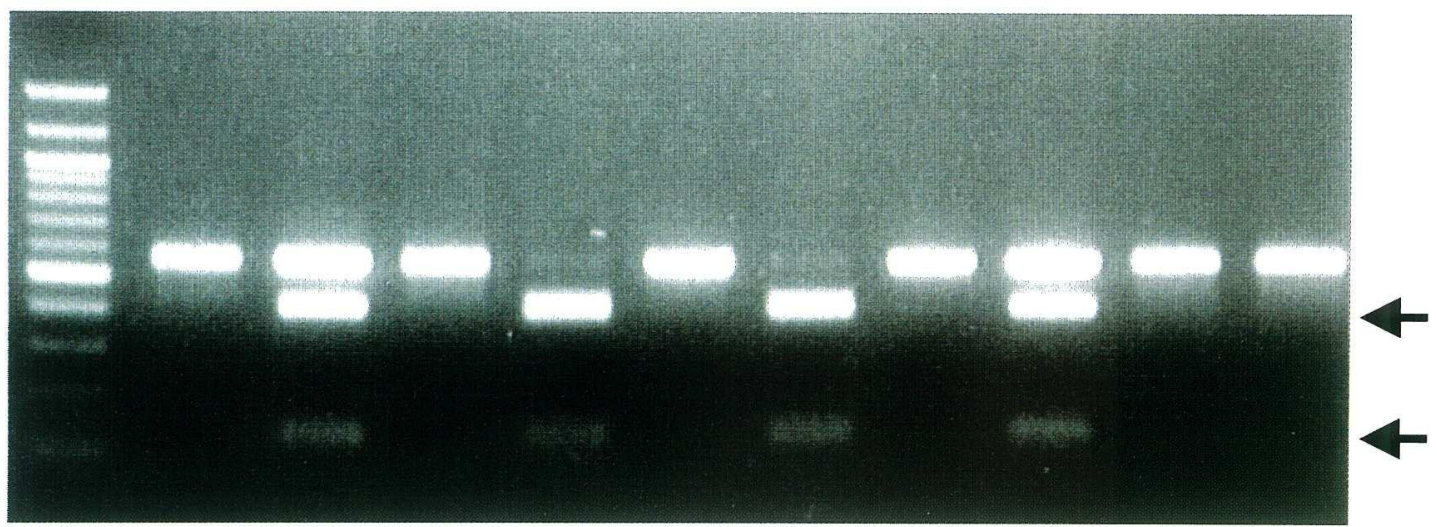

$100 \mathrm{bp}$

ladder
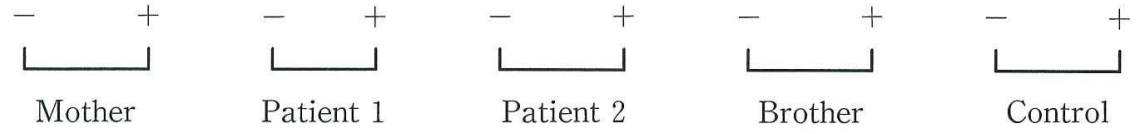

Figure 1. Sequence and restriction enzyme digestion analysis of $\mathrm{C} 3$ gene in patients with $\mathrm{C} 3$ deficiency. Upper panel. The direct sequence (reverse sequence) of the gene showed a homozygous point mutation (exon 26, C 3303 G, Tyr 1081 Stop) in the two sisters (A) and heterozygous mutation in their mother and a healthy brother (B). This substitution generated a new $B \ln I$ recognition site (right arrow). Lower panel. PCR products of $C 3$ were digested with $B \ln I$. The digestion products of the patients showed two DNA fragments (412 bp and $147 \mathrm{bp}$, arrows), while those of the mother and brother showed three DNA fragments. However, the PCR products of healthy volunteers remained undigested. +: digestion with the enzyme, -: no digestion with the enzyme.

digested by $B \ln$ I. The digestion products of the patients showed two DNA fragments (412 bp and $147 \mathrm{bp}$ ) while those of the mother and brother showed three DNA fragments. However, the PCR products of healthy volunteers remained undigested (Fig. 1). To evaluate the expression of the mutant $C 3$ cDNA, we constructed full-length normal and mutant $C 3 \mathrm{cDNA}$ and transfected into murine L-cells. After selection with neomycin, murine L-cells transfected with normal or mutant $C 3$ cDNA were harvested and analyzed by Western blot method. Although murine L-cells transfected with mutant $C 3$ did not produce $\mathrm{C} 3$ protein, a low level of mRNA was detectable (Fig. 2).

\section{Discussion}

Since the first case of inherited C3 deficiency described in 1972 (5), over 20 cases, including our original report, have been reported with a variety of ethnic and national origins (4).
The clinical features are characterized by recurrent infection and/or certain immune complex-related disorders, the pathomechanisms of which still remain to be identified (4-7). After the full genomic organization of the human $C 3$ gene was characterized (8), the molecular mechanisms for $\mathrm{C} 3$ deficiency were then studied. Five families, including the present cases, were examined for the molecular defects causing $\mathrm{C} 3$ deficiency (Table 2). The $C 3$ gene in two of the patients had a splicing defect. A G-A substitution of the $5^{\prime}$ splice donor site of intron 18 was found in the first patient, which resulted in a $61 \mathrm{bp}$ deletion of exon 18 (9). The second patient had a G-T substitution in the splice donor site of intron 10. This substitution resulted in exon 10 skipping during transcription and has been predicted to cause premature truncation of the $\mathrm{C} 3$ protein as a result of a frameshift mutation (10). A third patient had $800 \mathrm{bp}$ deletion leading to the loss of exon 22 and 23 of the $\alpha$-chain (11). Similarly, premature truncation of the protein has been 

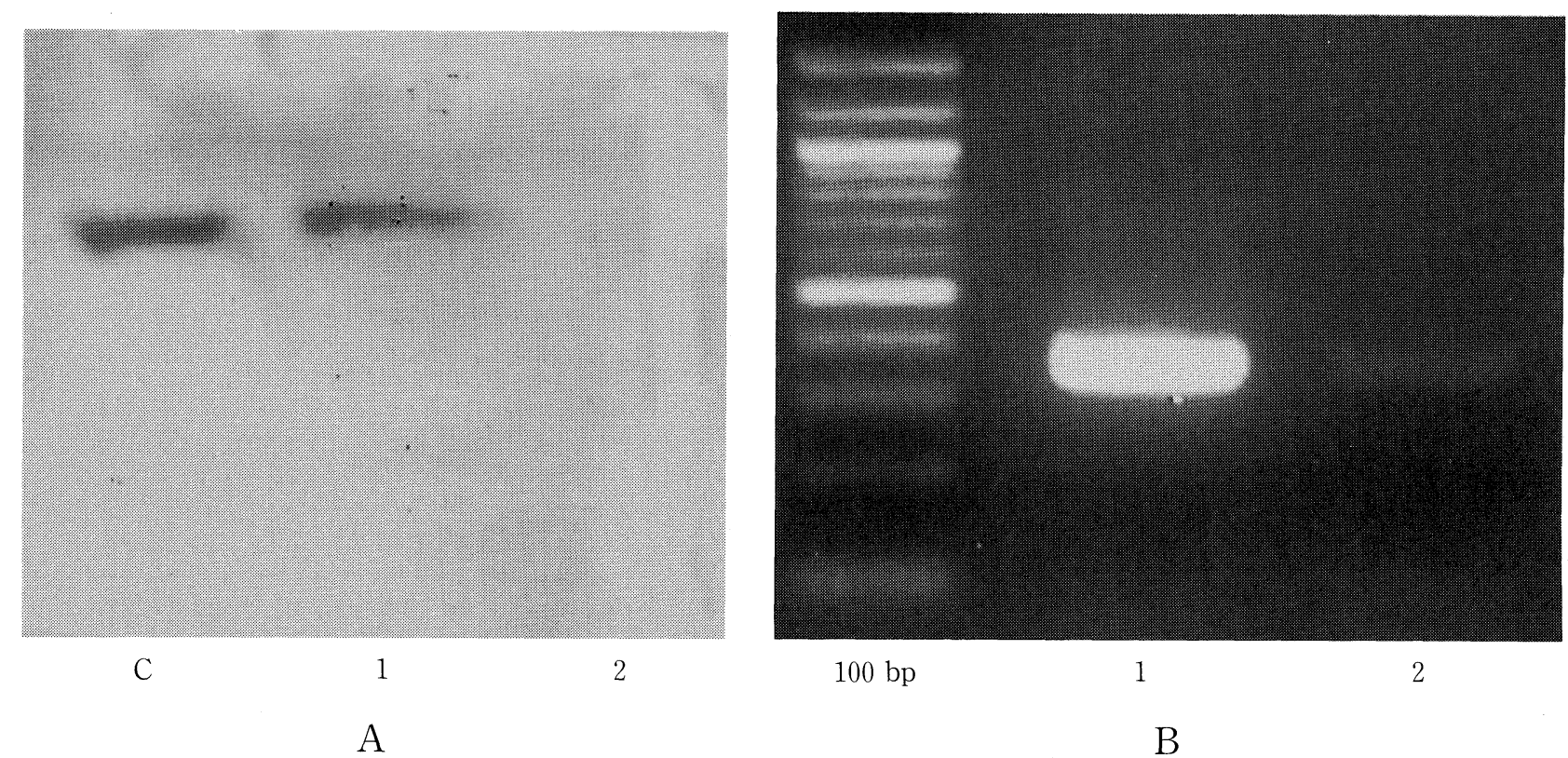

Figure 2. Expression study of $C 3$ in murine L-cells transfected with wild and mutant types $C 3$ cDNA. The L-cells transfected with mutant $C 3$ cDNA did not produce $C 3$ protein (A: Western blot analysis), however they expressed mRNA of $C 3$ (B: RT-PCR analysis). C: control C3 protein (Chemicon International, Temecula, CA, USA), 1: murine L-cells transfected with normal $C 3$ cDNA, 2: murine L-cells transfected with mutant $C 3$ cDNA, 100 bp: 100 bp ladder marker.

Table 2. Reported Cases of Hereditary C3 Deficiency with Molecular Analysis

\begin{tabular}{llll}
\hline Author (ref \#) & Patient & Gene abnormality & Symptoms \\
\hline Botto M et al (9) & 10 y.o. male & $\begin{array}{l}61 \text { bp deletion } \\
\text { (exon 18) }\end{array}$ & $\begin{array}{l}\text { Recurrent otitis media, convulsion, } \\
\text { erythema multiforme }\end{array}$ \\
Huang JL et al (10) & 22 y.o. female & $\begin{array}{l}\text { skipped exon 10 due to } \\
\text { G-T substitution (intron 10) }\end{array}$ & Recurrent meningitis, pneumonia \\
Botto M et al (11) & 34 y.o. female & $\begin{array}{l}\text { 800 bp deletion } \\
\text { (exon 22 \& 23) }\end{array}$ & Recurrent meningitis, facial rash \\
Singer L et al (12) & 18 y.o. male & $\begin{array}{l}\text { exon 13, G1705A } \\
\text { (Asp549Asn) }\end{array}$ & Periorbital cellulitis, recurrent pneumonia \\
Present cases/2001 & 36 y.o. female & $\begin{array}{l}\text { exon 26, C3303G } \\
\text { (Tyr1081Stop) } \\
\text { exon 26, C3303G } \\
\text { (Tyr1081Stop) }\end{array}$ & SLE-like symptoms \\
\hline 34 y.o. female & SLE-like symptoms
\end{tabular}

predicted to be the result of a frameshift mutation. The fourth patient had a critical amino acid substitution resulting in a secretion defect. In this patient, an Asp549Asn substitution was thought to interfere with the secretion of the $\mathrm{C} 3$ protein (12). In the present study, a stop codon was detected in exon 26 in the sisters. Initially we expected this mutation to result in the production of a truncated $\mathrm{C} 3$ protein, however the L-cells, transfected with mutant $C 3$ cDNA, expressed no protein while mRNA was detected at low levels. We thought of two possibilities to explain why the $\mathrm{C} 3$ protein was not detectable while mRNA was present. The first is that due to the mutation, the C3 protein is unstable and is easily degraded, therefore it be- 


\section{Matsuyama et al}

comes undetectable. The second possibility is that due to the mutation, the three-dimensional configuration of the $\mathrm{C} 3$ protein is changed, therefore it becomes undetectable. In either case, we suggest that this unstable and fragile or unusual form of mutant C3 protein may be responsible for the SLE-like symptoms such as arthritis.

The present cases did not show recurrent infections such as those previously reported (1-3, 5-7). Kitamura et al clearly showed that C5 compensated for the genetic lack of C3 and served a protective function (13). It may be possible that the patients' adaptive immune system is able to compensate for defective innate complement activity as previously reported (11).

C3 deficiency has been identified in about 20 unrelated patients, however the responsible mutations have been identified in only five of the families, including our cases. Continued investigation of the molecular basis of C3 deficiency will provide useful information concerning the biosynthesis, processing, and structure of the $\mathrm{C} 3$ protein as well as insight into the function of $\mathrm{C} 3$ and its products in the immune system.

Acknowledgement: We wish to thank Prof. Yoshito Eizuru (Division of Persistent and Oncogenic Viruses, Center for Chronic Viral Disease, Kagoshima University Faculty of Medicine) for donating the Epstein-Barr virus. The authors are grateful to Dr. A.R. Ng of Kagoshima University Faculty of Medicine for critical review, and Ms. S. Taniguchi and Ms. M. Miyazaki of Kagoshima University for their excellent technical assistance.

\section{References}

1) Ameratunga R, Winkelstein JA, Brody L, et al. Molecular analysis of the third component of canine complement (C3) and identification of the mutation responsible for hereditary canine $\mathrm{C} 3$ deficiency. J Immunol 160: 2824-2830, 1998.

2) Singer L, Colten HR, Wetsel RA. Complement C3 deficiency: human, animal and experimental models. Pathobiology 62: 14-28, 1994.

3) Botto M, Walport MJ. Hereditary deficiency of $\mathrm{C} 3$ in animals and humans. Int Rev Immunol 10: 37-50, 1993.

4) Sano Y, Nishimukai H, Kitamura H, et al. Hereditary deficiency of the third component of complement in two sisters with systemic lupus erythematosus-like symptoms. Arthritis Rheum 24: 1255-1260, 1981.

5) Alper CA, Colten HR, Rosen FS, Rabson AR, Macnab GM, Gear JS. Homozygous deficiency of $\mathrm{C} 3$ in a patient with repeated infections. Lancet ii: 1179-1181, 1972.

6) Hsieh KH, Lin CY, Lee TC. Complete absence of the third component of complement in a patient with repeated infections. Clin Immunol Immunopathol 20: 305-312, 1981.

7) Roord JJ, Daha M, Kuis W, et al. Inherited deficiency of the third component of complement associated with recurrent pyogenic infections, circulating immune complexes, and vasculitis in a Dutch family. Pediatrics 71: 81-87, 1983.

8) Fong KY, Botto M, Walport MJ, So AK. Genomic organization of human complement component C3. Genomics 7: 579-586, 1990.

9) Botto M, Fong KY, So AK, Rudge A, Walport MJ. Molecular basis of hereditary C3 deficiency. J Clin Invest 86: 1158-1163, 1990.

10) Huang JL, Lin CY. A hereditary $C 3$ deficiency due to aberrant splicing of exon 10. Clin Immunol Immunopathol 73: 267-273, 1994.

11) Botto M, Fong KY, So AK, Barlow R, Routier R. Homozygous hereditary C3 deficiency due to a partial gene deletion. Proc Natl Acad Sci USA 89: 4957-4961, 1992.

12) Singer L, Whitehead WT, Akama H, Katz Y, Fishelson Z, Wetsel RA. Inherited human complement C3 deficiency. J Biol Chem 269: 2849428499, 1994.

13) Kitamura H, Nishimukai H, Sano Y, Nagaki K. Study on C3-like factor in the serum of a C3-deficient subject. Immunology 51: 239-245, 1984. 